\title{
Treatment of Hyperlipidemia from Japanese Evidence
}

\author{
Shinji Koba ${ }^{1}$ and Jun Sasaki ${ }^{1,2}$
}

${ }^{1}$ The Third Department of Internal Medicine, Showa University School of Medicine, Tokyo, Japan.

${ }^{2}$ Graduate School of Public Health Medicine, International University of Health and Welfare, Fukuoka, Japan.

\begin{abstract}
The treatment of hyperlipidemia is aimed at preventing cardiovascular disease (CVD) and coronary heart disease (CHD). As the incidence of CHD in Japan is about one-third lower and that of stroke is two-fold higher compared to Western countries, and the doses of lipid-lowering drugs used in foreign randomized controlled clinical trials (RCTs) are much higher than in general use in Japan, it remains unclear whether the results of RCTs conducted in Western countries could be extrapolated to Japanese patients. Recently, two major large-scale, prospective, RCTs in Japanese hypercholesterolmic patients, the Management of Elevated Cholesterol in the Primary Prevention of Adult Japanese (MEGA) study and the Japan EPA Lipid Intervention Study (JELIS), have been reported. Japanese epidemiological studies and Japanese clinical studies are reviewed. The evidence suggests that hypercholesterolemia, hypertriglyceridemia, and low HDL-cholesterol are strongly associated with increased CHD risk. Lipid-lowering medication shows beneficial effects even in low-risk populations; however, the data did not support that lower cholesterol is better. The safety and efficacy of hyperlipidemia treatment in Japanese patients are discussed.
\end{abstract}

J Atheroscler Thromb, 2006; 13:267-280.

Key words; Hyperlipidemia, Randomized controlled trial, Cardiovascular disease, Coronary heart disease, Epidemiological study, Lipid-lowering therapy

\section{Introduction}

It is well established that hyperlipidemia is a major cause of the development of atherosclerotic cardiovascular disease (CVD), especially coronary heart disease (CHD). Thus, hyperlipidemia treatment is aimed at preventing CVD and CHD. Current national and international guidelines identify the reduction of lowdensity lipoprotein-cholesterol (LDL-C) levels as the primary target for cardiovascular risk reduction thera$\mathrm{py}^{1-3)}$. Hyperlipidemia includes both hypercholesterolemia and hypertriglyceridemia, and the latter is often associated with a spectrum of other lipid abnormalities which have atherogenic potential of their own. The so-called atherogenic lipoprotein profile or ath-

Address for correspondence: Jun Sasaki, Graduate School of Public Health Medicine, International University of Health and Welfare 1-3-1 Nagahama, Chuo-ku, Fukuoka 810-0072, Japan.

E-mail: jsas@nifty.com

Received: November 15, 2006

Accepted for publication: November 22, 2006 erogenic dyslipidemia consists of elevated levels of triglyceride, low levels of high density-lipoprotein-cholesterol (HDL-C), and the predominance of small dense $\mathrm{LDL}^{4)}$.

The National Cholesterol Education Program Adult Treatment Panel III (ATP-III) guidelines in the United States emphasize evidence based on a number of large epidemiological studies and many large, randomized, controlled clinical trials (RCTs ${ }^{2)}$. Many RCTs in Western countries have shown that the reduction of LDL-C levels by lipid-lowering therapy such as HMG CoA reductase inhibitors (statins) reduces the major coronary events and CHD mortality ${ }^{5-14}$. Recent studies have shown that the benefit of LDL-C-lowering therapy is observed regardless of the baseline levels of LDL-C in high-risk patients such as patients with previous $\mathrm{CHD}$, diabetic patients and patients with a clustering of risk factors ${ }^{12)}$. On the other hand, the incidence of CHD in Japan is about onefourth to one-third lower and that of stroke is twofold higher compared to Western countries ${ }^{15-18)}$. In addition, the dose of lipid-lowering drugs used in for- 
eign RCTs is much higher than in general use in Japan. Thus, it remains controversial whether the results of clinical studies conducted in Western countries could be extrapolated to Japanese patients. There had been few RCTs with Japanese patients until two major largescale, prospective, RCTs with statin and eicosapentaenoic acid (EPA) therapy in Japanese hypercholesterolemic patients were reported last November ${ }^{18,19)}$. The purpose of the present document is to review the Japanese evidence of hyperlipidemia as a risk factor for CVD and to discuss the treatment of hyperlipidemia from the viewpoint of the Japanese evidence.

\section{Epidemiological Studies in Japan}

\section{Hypercholesterolemia and CHD}

A 26-year follow-up of the Hiroshima-Nagasaki study of a fixed population of 13898 subjects in Hiroshima and 6063 subjects in Nagasaki which was conducted in 1958-1960, demonstrated an almost linear increase in the age-adjusted incidence of CHD and the relative risk of $\mathrm{CHD}$ in relation to serum cholesterol levels in both men and women ${ }^{20)}$. The cohort of the Hiroshima-Nagasaki Study is the Japanese cohort of the NI-HON-SAN Study, a well-known migration study; middle-aged Japanese men living in Japan, Honolulu, and San Francisco had progressively higher serum total-cholesterol (TC) and CHD death rates as their lifestyle became progressively westernized, including a shift toward a diet higher in animal fat ${ }^{21}$. In the Seven Countries Study, a population-based survey of 16 cohorts of men aged 40-59 years between 1959 and 1964, the relative risk for 5-year and 10-year CHD incidence was positively associated with serum TC levels; however, the association was less clear in Japan and Mediterranean South Europe ${ }^{22)}$. The Serum Lipid Survey in Japanese populations has shown gradual increases in serum TC levels from 1960 to 2000 due to the westernization of dietary habits ${ }^{23)}$.

In a number of epidemiological studies in Japan, NIPPON DATA 80 (National Integrated Project for Prospective Observation of Non-communicable Disease and Its Trends in the Aged, 1980) is a large prospective epidemiological study which reflects the Japanese population. This is a nationwide cardiovascular survey from 1980 and 10546 community-based subjects ( 4640 men and 5906 women) aged $\geqq 30$ years in 300 randomly selected health districts in all 47 prefectures participated. The 13.2-year prospective study of NIPPON DATA 80 showed a significantly positive relation of hypercholesterolemia ( $\geqq 240 \mathrm{mg} / \mathrm{dL}$ ) to CHD mortality and that the attributable risk percentage of hypercholesterolemia was $66 \%$ for $\mathrm{CHD}^{24)}$. The re- cent analysis of 159293 person-years with a mean follow-up of 17.3 years has shown that the highest TC ( $\geqq$ $6.71 \mathrm{mmol} / \mathrm{L}, 260 \mathrm{mg} / \mathrm{dL}$ ) at baseline had an increased risk of CHD (hazard ration [HR] 3.81; 95\% confidence interval $[\mathrm{CI}] 1.70-5.43)$ whereas the lowest TC $(<4.14 \mathrm{mmol} / \mathrm{L}, 160 \mathrm{mg} / \mathrm{dL})$ had an increased risk of liver disease ${ }^{25}$. After the exclusion of death due to liver disease during the entire follow-up period, increased HR in the lowest TC group disappeared and the HR for total mortality within the first 5 years of follow up in the highest TC group further increased (HR 1.48; 95\% CI 1.12-1.96), mainly as a consequence of CHD. These results were similar in gender-specific analysis, and were in good agreement with the Okinawa cohort study where mortality from CVD is the lowest and life expectancy is the highest in Japan ${ }^{26)}$. On the other hand, hypercholesterolemia was not a risk factor for stroke, which is in good agreement with the Hisayama Study, an established cohort study ${ }^{27)}$, and the mortality from cerebral hemorrhage was even the highest in the lowest TC group in men (HR 3.77; 95\% CI, 1.35 10.5). The recent risk assessment chart for death from CVD based on a 19-year follow-up NIPPON DATA 80 showed that the stroke chart was not graded by TC levels ${ }^{28)}$; therefore, hypercholesterolemia, especially higher than $260 \mathrm{mg} / \mathrm{dL}$ of TC and $160 \mathrm{mg} / \mathrm{dL}$ of LDL-C, has been shown to be positively associated with $\mathrm{CHD}$ mortality in Japan.

On the other hand, several epidemiological studies failed to show a positive relationship between serum TC and CHD incidence ${ }^{29,30)}$. A 15.5-year rural community-based cohort study in Niigata, which was conducted in 1977, has shown no relationship between serum TC and the occurrence of myocardial infarction $^{29)}$. There is a variation in the serum TC levels between rural and urban areas, and CHD mortality may be higher in the urban population than in the rural population ${ }^{30,31)}$. Thus, it seems likely that lifestyle affects serum lipid levels, and the morbidity and mortality of CHD.

\section{Hypertriglyceridemia, Low HDL-C and CHD}

Although the association between elevated serum TC levels and the increased risk of CHD is well established, the mean serum TC levels in Japanese are still one of the lowest in the world and even in Asia ${ }^{32)}$. A 15.5-year prospective study of 4452 men and 6616 women, aged 40-69 years, and free of CHD and stroke from 3 rural and one urban area demonstrated that non-fasting serum triglycerides are positively associated with the incidence of CHD in both men and women independently of TC and HDL-C ${ }^{33)}$. The significance of triglyceride as a risk factor for $\mathrm{CHD}$ was also 

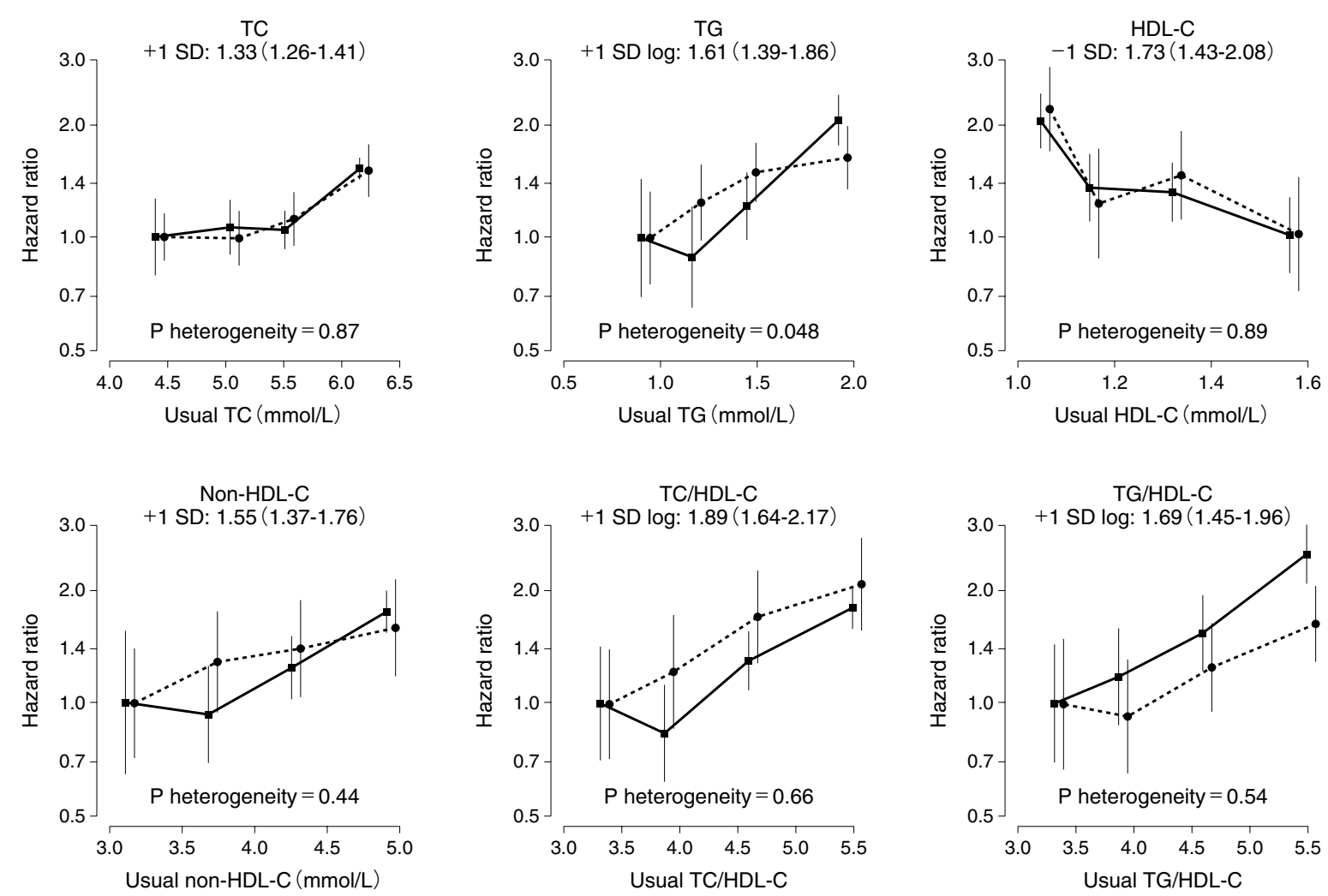

Fig. 1. Association between the usual levels of total cholesterol (TC), triglycerides (TG), HDL-cholesterol (HDL), non-HDL-cholesterol, and the ratios of TC/HDL and TG/HDL, and death due to coronary heart disease, in Asian (dashed line), and Australia and New Zealand (solid line) cohorts. Analyses are adjusted by study and sex (as stratification variables), age, current smoking, and systolic blood pressure. The hazard ratio and 95\% confidence interval for a one standard deviation (SD) higher level of TC, $\log$ TG, non-HDL, TC/ HDL-C, $\log$ (TG/HDL-C), and a one SD lower level of HDL-C are shown. The $p$ value for the heterogeneity of each association by region is also shown. $1 \mathrm{mmol} / \mathrm{L}$ (cholesterol) $=38.67 \mathrm{mg} / \mathrm{dL}, 1 \mathrm{mmol} / \mathrm{L}$ (triglyceride $)=88.57 \mathrm{mg} / \mathrm{dL}$. Adapted from reference 35 .

reported from international studies including Japanese cohorts $^{34)}$. The Asia-Pacific Cohort Studies Collaboration (APCSC) is a meta-analysis of prospective cohort studies to provide reliable evidence about the determinants of risk factors for CVD in the Asia Pacific region, including not only Asian countries but also Australia and New Zealand. The APCSC includes a number of Japanese cohorts such as Hisayama, Ohasama, and Tanno/Soubetsu. Meta-analysis of 26 studies in APCSC with 96224 individuals and 796671 personyear follow-up have shown that increased baseline triglyceride levels are significantly associated with fatal and non-fatal CHD, and fatal and non-fatal cerebral infarction, independently of other major risk factors including HDL-C ${ }^{34)}$. Recent meta-analysis in comparison with risk factors between Asian and white populations (Australia) has demonstrated that high TC, high triglyceride, high non-HDL-C, and low HDL-C are each independent risk factors for CHD death in both Asia and Australia (Fig. 1) ${ }^{34)}$. In addition, triglyceride and the triglyceride/HDL-C ratio were more informative predictors for CHD than $\mathrm{TC}^{35}$.

Hypertriglyceridemia is often associated with lowHDL-C, both of which are integral components of metabolic syndrome ${ }^{36,37)}$. Several case-control studies including ours ${ }^{38-41)}$ and a prospective observational study ${ }^{42)}$ have shown that low-HDL-C and high triglyceride are important risk factors for $\mathrm{CHD}$ as well as hypercholesterolemia. Recent studies suggest that high triglyceride and/or low HDL-C are strongly associated with the predominance of highly atherogenic small dense LDL ${ }^{41,43-45)}$. The Honolulu Heart Program, a population study of older Japanese-American men living in Oahu, demonstrated that the composite risk factor for small LDL, triglyceride and HDL-C is an increased risk for CHD independent of other risk factors ${ }^{45)}$. In addition, the recent Framingham study has shown that increased small LDL-C evaluated by NMR 
spectroscopy is closely associated with metabolic syndrome $^{44)}$. Atherogenic hypertriglyceridemia and/or low HDL-C should be an alternative target for the prevention of CVD.

\section{Cohort Study of Hypercholesterolemic Patients with Statins}

The Japan Lipid Intervention Trial (J-LIT) was the first nationwide 6-year cohort study of 41801 hypercholesterolemic patients without a prior history of CHD and 4599 hypercholesterolemic patients with CHD, aged 35 to 70 years in men and postmenopausal women aged under 70 years, with open-labeled simvastatin (5-10 $\mathrm{mg}$ daily) treatment to determine the relationship between the occurrence of CHD and serum lipid levels ${ }^{46-49)}$. This study was designed in 1990 and $67 \%$ of the participants were women. Simvastatin reduced LDL-C levels by 27\%. During the 6 years of simvastatin treatment, the incidence of $\mathrm{CHD}$ was much higher in the secondary prevention cohort than that in the primary prevention cohort (4.45 vs 0.91 per 1000 patient years, respectively). Although we could not conclude the evidence of risk reduction of $\mathrm{CHD}$ by simvastatin treatment because of no intervention trial, J-LIT showed the significance of a clustering of risk factors for CHD. Male patients had a 2.3-fold higher risk of CHD onset and a 2.6-fold higher risk of $\mathrm{CHD}$ recurrence compared with female patients. Diabetes was an increased risk in both primary and secondary prevention. Elderly patients aged older than 65 years, and patients with hypertension, a family history of CHD or smoking habit showed an increased risk of CHD onset. The onset and recurrence of coronary events were each positively and inversely associated with averaged concentrations of LDL-C and HDL$\mathrm{C}$ in 6-year simvastatin treatment, respectively, whereas the averaged triglyceride levels did not correlate with the recurrence of CHD in secondary prevention. In addition, the recent sub-analysis of 41088 patients without a history of CHD and cerebrovascular disease showed that not cerebral hemorrhage but cerebral infarction was significantly associated with high TC ( $\geqq$ $240 \mathrm{mg} / \mathrm{dL})$, high LDL-C $(\geqq 160 \mathrm{mg} / \mathrm{dL})$, high triglyceride $(\geqq 150 \mathrm{mg} / \mathrm{dL})$ and low HDL-C $(<40 \mathrm{mg} /$ $\mathrm{dL})^{49)}$. Simvastatin was well tolerated and adverse side effects were reported in $3.2 \%$ over 6 years. No case of rhabdomyolysis was observed ${ }^{46)}$.

\section{Review of Clinical Trials in Japan}

As Japanese physicians rejected the determined rules of randomization, and placebo-controlled trials are unethical, we had very few RCTs. Tables $\mathbf{1}, \mathbf{2}$, and 3 compare Japanese clinical trials and major RCTs in the West. We have one observational study and three RCTs, all of which used pravastatin in hypercholesterolemic patients. It is very difficult to compare the results of Japanese RCTs to Western RCTs because of the different incidence of events, endpoints and clinical characteristics of the studied population. While most primary endpoints in Western RCTs are hard events such as all-cause death, CHD death and fatal or non-fatal myocardial infarction, the primary endpoints of Japanese RCTs are coronary events including angina pectoris, coronary revascularization, and/or unexpected or sudden death because of much lower CHD mortality compared with other countries.

\section{Observational Study \\ The Kyushu Lipid Intervention Study (KLIS)}

The KLIS was designed as the first large-scale RCT to investigate the effects of pravastatin in the primary prevention of CHD events and cerebral infarction in Japan. A total of 5640 Japanese men, aged 45 to 74 years with hypercholesterolemia ( $T C \geqq 220 \mathrm{mg}$ / $\mathrm{dL})$, were randomly allocated to either pravastatin (10 to $20 \mathrm{mg}$ daily) or conventional treatment other than statins, probucol and bezafibrate ${ }^{50)}$; however, the participating physicians did not necessarily follow the instructions of the random assignment, and the number of patients and baseline lipid levels were quite different between pravastatin and conventional treatment groups. Thus, the results should be interpreted as an observational study. After a 5-year follow-up period, pravastatin reduced LDL-C by $20 \%$ while conventional therapy reduced LDL-C by $10 \%$. The incidence of CHD including myocardial infarction, coronary revascularization procedure, and cardiac or unexpected death and/or cerebral infarction was 9.77 per 1000 patient years in the pravastatin group and 10.99 per patient years in the conventional therapy group. The risk of CHD and/or cerebral infarction was 19\% lower $(p=0.08)$ and the total mortality was $21 \%$ lower $(p=0.08)$ in pravastatin treatment. When the pravastatin group was divided into two subgroups of poor and good compliance, the good-compliance pravastatin treatment reduced LDL-C by $10 \%$ and significantly reduced the risk of CHD and/or cerebral infarction by $27 \%(p=0.04)$ compared to conventional treatment. The recent sub-analysis of KLIS to compare the relation of serum lipid levels to CHD events between middle-aged ( $<65$ years) and elderly men $(\geqq$ 65 year) has shown that serum TC concentration during the follow-up period, not at the baseline, was related to an increased risk of CHD in elderly men ${ }^{51)}$. 
Table 1. Comparison of characteristics between Japanese clinical trials and major randomized controlled trials in Western countries

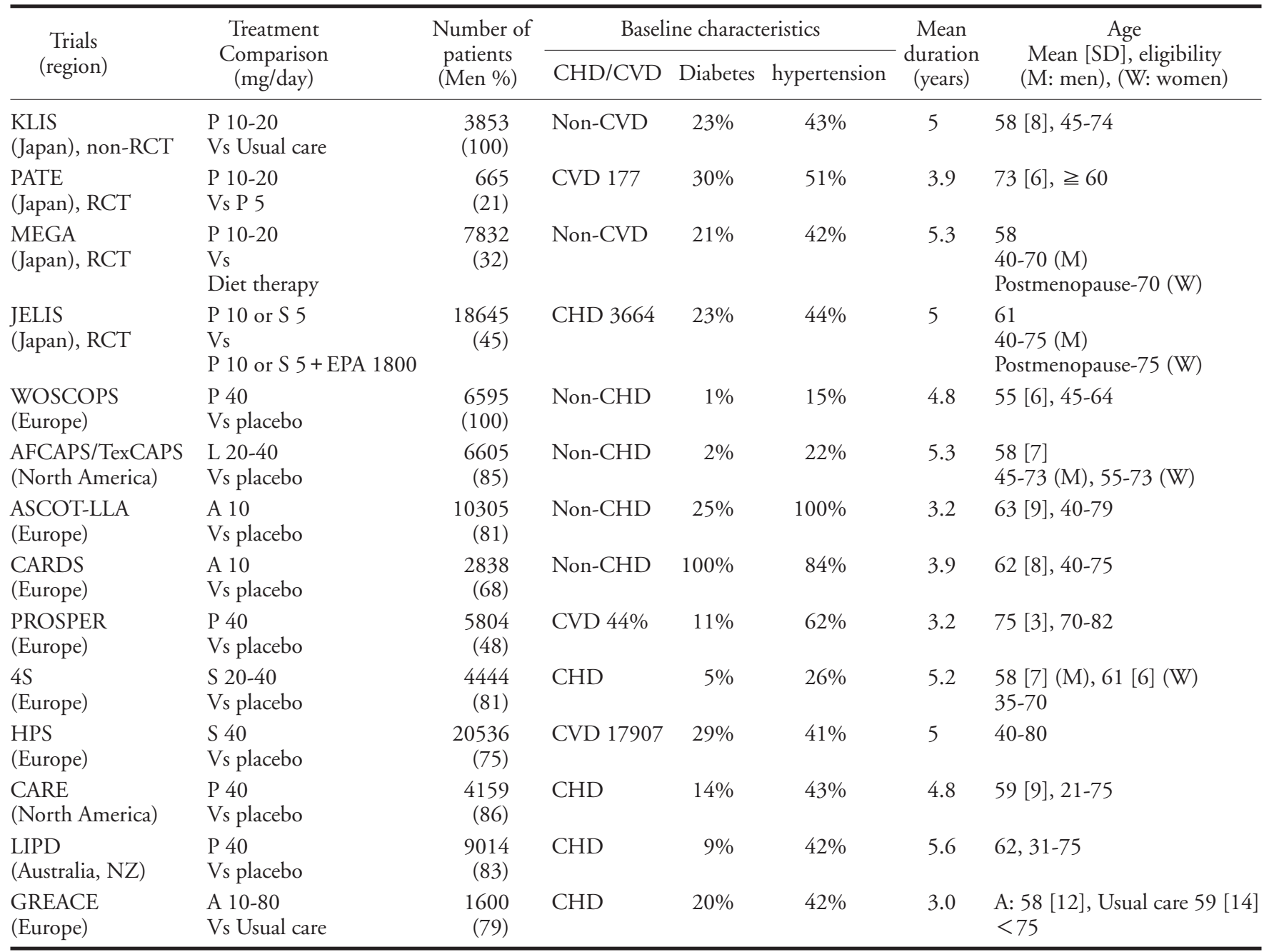

P 5-40: pravastatin $5 \mathrm{mg}-40 \mathrm{mg}, \mathrm{S} 5-40$ : simvastatin $5 \mathrm{mg}-40 \mathrm{mg}$, L 20-40: lovastatin $20 \mathrm{mg}-40 \mathrm{mg}$, A 10-80: atorvastatin $10 \mathrm{mg}-80 \mathrm{mg}$, U: usual care $\mathrm{NZ}=\mathrm{New} Z$ Zealand, $\mathrm{CHD}=$ coronary heart disease, $\mathrm{CVD}=$ cardiovascular disease, $\mathrm{M}=$ men, $\mathrm{W}=$ women

The KLIS has shown that high serum TC levels with treatment are a significant risk for CHD in hypercholesterolemic elderly men.

\section{Randomized Controlled Trials (RCTs) \\ The Pravastatin Anti-atherosclerosis Trial in the Elderly (PATE)}

The PATE is the first prospective RCT in the world for only hypercholesterolemic elderly patients, aged $\geqq 60$ years. This study was started in 1990 , and at that time, no large RCT had been reported. Six hundred and sixty-five hypercholesterolemic elderly men and women both with and without previous $\mathrm{CHD}$ randomly received either a low dose $(5 \mathrm{mg} /$ day $)$ or standard dose $(10-20 \mathrm{mg} /$ day $)$ of pravastatin ${ }^{52)}$. Baseline TC levels were similar in the 2 groups (253 \pm
$15 \mathrm{mg} / \mathrm{dL}$ ); however, the proportion of women was significantly more in the standard-dose group than in the low-dose group. With treatment TC levels were $209 \pm 2 \mathrm{mg} / \mathrm{dL}$ in the standard dose and $221 \pm 2 \mathrm{mg} /$ $\mathrm{dL}$ in the low dose. The decrease of TC and LDL-C, calculated using Friedewald's formula, and triglyceride, and the increase of HDL-C were significantly greater in the standard-dose group than in the lowdose group at all time points; however, the difference of TC was 10-14 mg/dL, which was smaller than that reported in the West. Nevertheless, the incidence of fatal and non-fatal cardiovascular events was significantly lower in the standard-dose group than in the low-dose group $(p=0.0046$, generalized Wilcoxon test; $p=0.096$, log-rank test) at a mean follow-up of 3.9 years. The risk reduction for cardiovascular events in 
Table 2. Comparison of lipid levels between Japanese clinical trials and major randomized controlled trials in Western countries

\begin{tabular}{|c|c|c|c|c|c|c|c|c|}
\hline $\begin{array}{l}\text { Trials } \\
\text { (region) }\end{array}$ & \multicolumn{2}{|r|}{ T-C } & \multicolumn{2}{|r|}{ LDL-C } & \multicolumn{2}{|c|}{ HDL-C } & \multicolumn{2}{|c|}{ TG } \\
\hline $\begin{array}{l}\text { PATE } \\
\text { (Japan), RCT }\end{array}$ & $\begin{array}{l}253 \\
(220-280)\end{array}$ & $\begin{array}{c}\mathrm{P} 10-38-42 \mathrm{mg} / \mathrm{dL} \\
-15-17 \% \\
\mathrm{P} 5-28-32 \mathrm{mg} / \mathrm{dL} \\
-11-13 \%\end{array}$ & $\begin{array}{l}\text { P10 166, } \\
\text { P5 } 164\end{array}$ & $\begin{array}{c}\mathrm{P} 10-39-43 \mathrm{mg} / \mathrm{dL} \\
-23-26 \% \\
\mathrm{P} 5-30-34 \mathrm{mg} / \mathrm{dL} \\
-17-20 \%\end{array}$ & 55 & & $\begin{array}{l}\text { P10 153, } \\
\text { P5 } 152\end{array}$ & \\
\hline $\begin{array}{l}\text { MEGA } \\
\text { (Japan), RCT }\end{array}$ & $\begin{array}{l}243 \\
(220-270)\end{array}$ & $-11.5 \%$ & 157 & $-18.0 \%$ & 58 & $5.8 \%$ & 127 & $-8.1 \%$ \\
\hline $\begin{array}{l}\text { JELIS } \\
\text { (Japan), RCT }\end{array}$ & $\begin{array}{l}275 \\
(\geqq 250)\end{array}$ & $-19 \%$ & 182 & $\begin{array}{l}49 \mathrm{mg} / \mathrm{dL} \\
-26 \%\end{array}$ & & & & $\begin{array}{l}-4 \% \text { (control) } \\
-9 \% \text { (EPA) }\end{array}$ \\
\hline $\begin{array}{l}\text { WOSCOPS } \\
\text { (Europe) }\end{array}$ & $\begin{array}{l}272 \\
(\geqq 252)\end{array}$ & $-20 \%$ & $\begin{array}{l}192 \\
(\geqq 155)\end{array}$ & $-26 \%$ & 44 & $5 \%$ & 164 & $-12 \%$ \\
\hline $\begin{array}{l}\text { ASCOT-LLA } \\
\text { (Europe) }\end{array}$ & $\begin{array}{l}213 \\
(\leqq 250)\end{array}$ & $-50 \mathrm{mg} / \mathrm{dL}$ & 131 & $-41 \mathrm{mg} / \mathrm{dL}$ & 50 & 0 & $\begin{array}{l}146 \\
(<400)\end{array}$ & $-33 \mathrm{mg} / \mathrm{dL}$ \\
\hline $\begin{array}{l}\text { CARDS } \\
\text { (Europe) }\end{array}$ & 207 & $\begin{array}{l}-48 \mathrm{mg} / \mathrm{dL}^{*} \\
-26 \% *\end{array}$ & $\begin{array}{l}117 \\
(\leqq 160)\end{array}$ & $\begin{array}{l}-46 \mathrm{mg} / \mathrm{dL}^{*} \\
-40 \% *\end{array}$ & 54 & $\begin{array}{l}0.8 \mathrm{mg} / \mathrm{dL}^{*} \\
1 \% *\end{array}$ & $\begin{array}{l}150 \\
(\leqq 600)\end{array}$ & $\begin{array}{l}-35 \mathrm{mg} / \mathrm{dL}^{*} \\
-19 \% *\end{array}$ \\
\hline $\begin{array}{l}\text { PROSPER } \\
\text { (Europe) }\end{array}$ & $\begin{array}{l}221 \\
(155-348)\end{array}$ & & 147 & $\begin{array}{l}-50 \mathrm{mg} / \mathrm{dL} \\
-32 \%\end{array}$ & 50 & $5 \%$ & $\begin{array}{l}133 \\
(<531)\end{array}$ & $-12 \%$ \\
\hline $\begin{array}{l}4 S \\
\text { (Europe) }\end{array}$ & $\begin{array}{l}260 \\
(212-309)\end{array}$ & $-26 \%$ & 188 & $-36 \%$ & 46 & $7 \%$ & $\begin{array}{l}133 \\
(\leqq 221)\end{array}$ & $-17 \%$ \\
\hline $\begin{array}{l}\text { HPS } \\
\text { (Europe) }\end{array}$ & $\begin{array}{l}228 \\
(\geqq 135)\end{array}$ & $-46 \mathrm{mg} / \mathrm{dL}$ & 131 & $-39 \mathrm{mg} / \mathrm{dL}$ & 41 & $1 \mathrm{mg} / \mathrm{dL}$ & 186 & $-27 \mathrm{mg} / \mathrm{dL}$ \\
\hline $\begin{array}{l}\text { CARE } \\
\text { (North America) }\end{array}$ & $\begin{array}{l}209 \\
(<240)\end{array}$ & $-20 \% *$ & $\begin{array}{l}139 \\
(115-174)\end{array}$ & $\begin{array}{l}-42 \mathrm{mg} / \mathrm{dL} \\
-32 \%,-28 \% *\end{array}$ & 39 & $5 \% *$ & $\begin{array}{l}155 \\
(\leqq 350)\end{array}$ & $-14 \% *$ \\
\hline
\end{tabular}

* Compared to the placebo group, See Table 1 for abbreviations.

the standard-dose group was more striking in non-diabetic patients, patients aged less than 72 years, patients with TC levels less than $253 \mathrm{mg} / \mathrm{dL}$ or patients with triglyceride levels $\geqq 133 \mathrm{mg} / \mathrm{dL}$ in comparison with each counterpart. However, cardiovascular event endpoints included various cardiovascular events including cerebral infarction, cerebral hemorrhage, transient ischemic attack, subarachnoidal hemorrhage, congestive heart failure due to ischemic heart disease, arrhythmia requiring pharmacological treatment, dissecting aortic aneurysm, and peripheral arterial thrombosis, which was quite different from other RCTs in the West. The prevalence of adverse events other than cardiovascular events was similarly low in both groups. This study demonstrated that pravastatin at the standard dose is safe and useful to prevent cardiovascular disease than low-dose pravastatin even in elderly hypercholesterolemic Japanese patients who are at high risk for CHD and CVD.

The Management of Elevated Cholesterol in the Primary Prevention of Adult Japanese (MEGA) Study

The MEGA study is the first prospective RCT in Asia. In this study, 7832 hypercholesterolemic patients, men aged 40 to 70 years and postmenopausal women aged less than 70 years, TC levels $220-270 \mathrm{mg} / \mathrm{dL}$ and without any CVD, were randomly allocated to diet therapy or diet plus pravastatin (10 to $20 \mathrm{mg}$ daily $)^{18)}$. Of the patients, $68 \%$ were women, $42 \%$ had hypertension and $21 \%$ had diabetes. These subject types are commonly seen in clinical practice in Japan. The HDL$\mathrm{C}$ level at baseline was $57.5 \mathrm{mg} / \mathrm{dL}$, which was mark- 
Table 3. Comparison of outcomes between Japanese clinical trials and major randomized controlled trials in Western countries

\begin{tabular}{|c|c|c|c|c|c|c|c|}
\hline \multirow{3}{*}{$\begin{array}{l}\text { Trials (region) } \\
\text { KLIS } \\
\text { (Japan), non-RCT }\end{array}$} & \multirow{3}{*}{$\begin{array}{l}\text { Endpoints } \\
\text { ronary events }{ }^{\dagger} \\
\text { ronary events, Cerebral infarction } \\
\text { cause death }\end{array}$} & \multicolumn{4}{|c|}{ Incidence of events (\%) } & \multicolumn{2}{|c|}{ Relative risk reduction } \\
\hline & & \multicolumn{2}{|c|}{ treatment } & \multicolumn{2}{|c|}{ control } & \multirow{2}{*}{$\begin{array}{l}\%(95 \% \mathrm{CI}) \\
14(-20 \text { to } 39) \\
19(-4 \text { to } 39) \\
21(-4 \text { to } 40)\end{array}$} & \multirow{2}{*}{$\begin{array}{l}\mathrm{p} \\
\mathrm{NS} \\
\mathrm{NS} \\
\mathrm{NS}\end{array}$} \\
\hline & & P 10-20 & $\begin{array}{l}2.9 \\
4.9 \\
3.9\end{array}$ & Usual care & $\begin{array}{l}2.9 \\
5.3 \\
4.8\end{array}$ & & \\
\hline $\begin{array}{l}\text { PATE } \\
\text { (Japan), RCT }\end{array}$ & $\begin{array}{l}\text { 1, Cerebrovascular and cardiovascular disease }{ }^{\dagger} \\
2, \text { MI, AP } \\
2 \text {, All-cause death }\end{array}$ & P 10-20 & $\begin{array}{l}8.8 \\
3.0 \\
4.2\end{array}$ & P 5 & $\begin{array}{r}12.6 \\
5.1 \\
6.0\end{array}$ & $33(-7$ to 55$)$ & $\begin{array}{l}\text { NS } \\
\text { NS } \\
\text { NS }\end{array}$ \\
\hline $\begin{array}{l}\text { MEGA } \\
\text { (Japan), RCT }\end{array}$ & $\begin{array}{l}\text { 1, CHD (MI, AP, cardiac or sudden death, re- } \\
\text { vascularization) } \\
\text { 2, CHD + Cerebral infarction } \\
\text { 3, All-cause death }\end{array}$ & P $10-20$ & $\begin{array}{l}2.5 \\
1.4\end{array}$ & Diet & $\begin{array}{l}3.6 \\
2.0\end{array}$ & $\begin{array}{l}30(10 \text { to } 46) \\
28(-1 \text { to } 49)\end{array}$ & $\begin{array}{l}0.005 \\
0.055\end{array}$ \\
\hline $\begin{array}{l}\text { JELIS } \\
\text { (Japan), RCT }\end{array}$ & $\begin{array}{l}\text { 1, Coronary events }{ }^{\S} \\
\text { 2, All-cause death }\end{array}$ & $\begin{array}{l}\text { Statin }+ \\
\text { EPA }\end{array}$ & $\begin{array}{l}2.8 \\
3.1\end{array}$ & Statin & $\begin{array}{l}3.5 \\
2.8\end{array}$ & $\begin{array}{l}19(5 \text { to } 31) \\
-9(-28 \text { to } 8)\end{array}$ & $\begin{array}{l}0.011 \\
\text { NS }\end{array}$ \\
\hline $\begin{array}{l}\text { WOSCOPS } \\
\text { (Europe) }\end{array}$ & $\begin{array}{l}\text { 1, Non-fatal MI, coronary death } \\
\text { 2, CVD death } \\
\text { 2, All-cause death }\end{array}$ & Р 40 & $\begin{array}{l}5.5^{*} \\
1.6^{*} \\
3.2^{*}\end{array}$ & Placebo & $\begin{array}{l}7.9^{*} \\
2.3^{*} \\
4.1^{*}\end{array}$ & $\begin{array}{l}31(17 \text { to } 43) \\
32(3 \text { to } 53) \\
22(0 \text { to } 40)\end{array}$ & $\begin{array}{r}<0.001 \\
0.033 \\
0.051\end{array}$ \\
\hline $\begin{array}{l}\text { AFCAPS/TexCAPS } \\
\text { (North America) }\end{array}$ & $\begin{array}{l}\text { 1, fatal or non-fatal MI, sudden death, UAP } \\
\text { 2, Coronary revascularization } \\
\text { 2, Fatal or non-fatal MI }\end{array}$ & L 20-40 & $\begin{array}{l}3.5 \\
3.2 \\
1.7\end{array}$ & Placebo & $\begin{array}{l}5.5 \\
4.8 \\
2.9\end{array}$ & $\begin{array}{l}37(21 \text { to } 50) \\
40(17 \text { to } 57) \\
33(15 \text { to } 48)\end{array}$ & $\begin{array}{r}<0.001 \\
0.001 \\
0.002\end{array}$ \\
\hline $\begin{array}{l}\text { ASCOT-LLA } \\
\text { (Europe) }\end{array}$ & $\begin{array}{l}\text { 1, Non-fatal MI, fatal CHD } \\
\text { 2, Total cardiovascular events including revascu- } \\
\quad \text { larization } \\
\text { 2, Total coronary events } \\
\text { 2, All-cause death }\end{array}$ & A 10 & $\begin{array}{l}1.9 \\
7.5 \\
3.4 \\
3.6\end{array}$ & Placebo & $\begin{array}{l}3.0 \\
9.5 \\
4.8 \\
4.1\end{array}$ & $\begin{array}{l}36(17 \text { to } 50) \\
21(10 \text { to } 31)\end{array}$ & $\begin{array}{l}0.0005 \\
0.0005 \\
0.0236 \\
\text { NS }\end{array}$ \\
\hline $\begin{array}{l}\text { CARDS } \\
\text { (Europe) }\end{array}$ & $\begin{array}{l}\text { 1, Acute coronary events, coronary revascular- } \\
\text { ization, stroke } \\
\text { 2, All-cause death } \\
\text { 2, Acute hospital-verified cardiovascular events }\end{array}$ & A 10 & $\begin{array}{l}5.8 \\
4.3 \\
9.4\end{array}$ & Placebo & $\begin{array}{r}9.0 \\
5.8 \\
13.4\end{array}$ & $\begin{array}{l}37(17 \text { to } 52) \\
27(-1 \text { to } 48) \\
32(15 \text { to } 45)\end{array}$ & $\begin{array}{l}0.001 \\
0.059 \\
0.001\end{array}$ \\
\hline $\begin{array}{l}\text { PROSPER } \\
\text { (Europe) }\end{array}$ & $\begin{array}{l}\text { 1, CHD death, non-fatal MI, stroke } \\
\text { 2, CHD death, non-fatal MI }\end{array}$ & P 40 & $\begin{array}{l}14.1 \\
10.1\end{array}$ & Placebo & $\begin{array}{l}16.2 \\
12.2\end{array}$ & $\begin{array}{l}15(3-26) \\
19(6-31)\end{array}$ & $\begin{array}{l}0.014 \\
0.006\end{array}$ \\
\hline $\begin{array}{l}4 S \\
\text { (Europe) }\end{array}$ & $\begin{array}{l}\text { 1, All-cause death } \\
\text { 2, Major coronary events } \\
\text { 3, Coronary revascularization }\end{array}$ & S $20-40$ & $\begin{array}{r}8.2 \\
19.0 \\
11.3\end{array}$ & Placebo & $\begin{array}{l}11.5 \\
28.0 \\
17.2\end{array}$ & $\begin{array}{l}30(15 \text { to } 42) \\
34(15 \text { to } 41) \\
37(26 \text { to } 46)\end{array}$ & $\begin{aligned} & 0.0003 \\
< & 0.00001 \\
< & 0.00001\end{aligned}$ \\
\hline $\begin{array}{l}\text { HPS } \\
\text { (Europe) }\end{array}$ & $\begin{array}{l}\text { 1, All-cause death } \\
\text { 2, Any vascular death } \\
3 \text {, Non-fatal MI, CHD death }\end{array}$ & S 40 & $\begin{array}{r}12.9 \\
7.6 \\
8.7\end{array}$ & Placebo & $\begin{array}{r}14.7 \\
9.1 \\
11.8\end{array}$ & $\begin{array}{l}13(6 \text { to } 29) \\
17(9 \text { to } 25) \\
27(11 \text { to } 33)\end{array}$ & $\begin{array}{r}0.0003 \\
<0.0001 \\
<0.0001\end{array}$ \\
\hline $\begin{array}{l}\text { CARE } \\
\text { (North America) }\end{array}$ & $\begin{array}{l}\text { 1, Fatal CHD, non-fatal MI } \\
\text { 2, Coronary revascularization }\end{array}$ & P 40 & $\begin{array}{l}10.2 \\
14.1\end{array}$ & Placebo & $\begin{array}{l}13.2 \\
18.8\end{array}$ & $\begin{array}{l}24(9 \text { to } 36) \\
27(15 \text { to } 37)\end{array}$ & $\begin{array}{r}0.003 \\
<0.001\end{array}$ \\
\hline $\begin{array}{l}\text { LIPD } \\
\text { (Australia, NZ) }\end{array}$ & $\begin{array}{l}\text { 1, CHD death } \\
2 \text {, All-cause death }\end{array}$ & P 40 & $\begin{array}{r}6.4 \\
11.0\end{array}$ & Placebo & $\begin{array}{r}8.3 \\
14.1\end{array}$ & $\begin{array}{l}24(12 \text { to } 35) \\
22(13 \text { to } 31)\end{array}$ & $\begin{array}{l}<0.001 \\
<0.001\end{array}$ \\
\hline $\begin{array}{l}\text { GREACE } \\
\text { (Europe) }\end{array}$ & $\begin{array}{l}\text { 1, All-cause death } \\
1, \text { CHD death } \\
1, \text { Non-fatal MI }\end{array}$ & A $10-80$ & $\begin{array}{l}2.9 \\
2.5 \\
2.6\end{array}$ & Usual care & $\begin{array}{l}5 \\
4.8 \\
6.4\end{array}$ & $\begin{array}{l}43 \\
47 \\
59\end{array}$ & $\begin{array}{l}0.0021 \\
0.0017 \\
0.0001\end{array}$ \\
\hline
\end{tabular}

Endpoint-1 = primary endpoints, $2=$ secondary endpoints, $3=$ other principal endpoints. ${ }^{\dagger}$ KLIS coronary events=fatal and non-fatal MI, coronary revascularization procedure, cardiac death, sudden and unexpected death. ${ }^{\dagger}$ PATE primary events= cerebral infarction, cerebral hemorrhage, transient ischemic attack, subarachnoidal hemorrhage, congestive heart failure due to ischemic heart disease, arrhythmia requiring pharmacological treatment, dissecting aortic aneurysm, ASO, dissecting aortic aneurysm, peripheral arterial thrombosis. ${ }^{\S}$ JELIS coronary events=fatal and non-fatal MI, unstable angina, coronary revascularization procedure, $\mathrm{CHD}$ death, sudden cardiac death, non-fatal coronary events, Major coronary events $=$ coro-

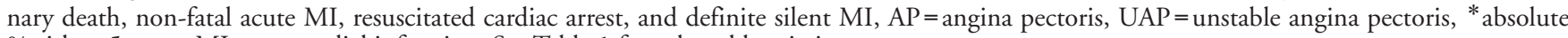
$\%$ risk at 5 years, $\mathrm{MI}=$ myocardial infarction, See Table 1 for other abbreviations.

edly higher than other RCTs, suggesting a low-risk population. Pravastatin reduced LDL-C levels by $18 \%$ whereas LDL-C decreased by $3.2 \%$ in the diet group.
At a mean follow-up of 5.3 years, the onset of CHD defined as fatal or non-fatal myocardial infarction, sudden death, angina pectoris and coronary revascu- 


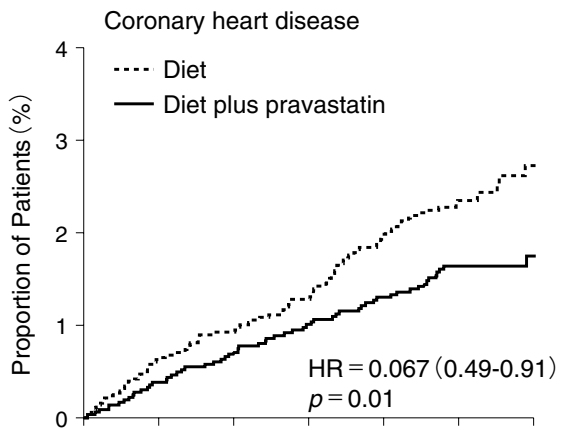

\section{Number at risk}

Diet

$\begin{array}{lllllllll}\text { Diet plus pravastatin } & 3866 & 3642 & 3490 & 3385 & 3307 & 2434 & 859\end{array}$

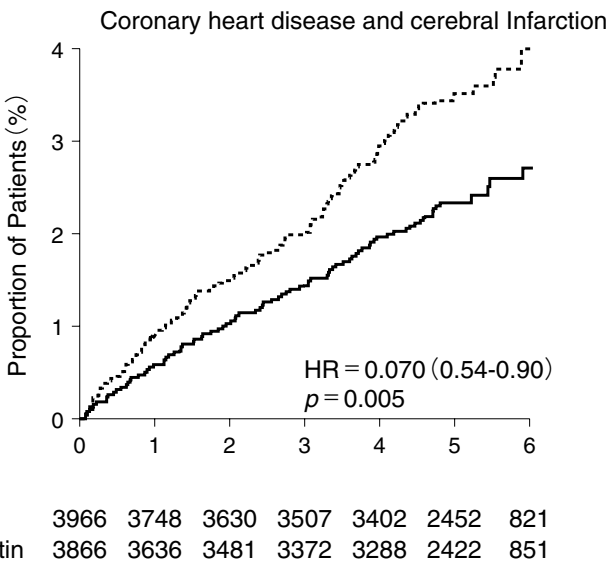

Number at risk

Diet

Diet plus pravastatin $\begin{array}{lllllll}3966 & 3758 & 3648 & 3529 & 3430 & 2476 & 830\end{array}$
Stroke

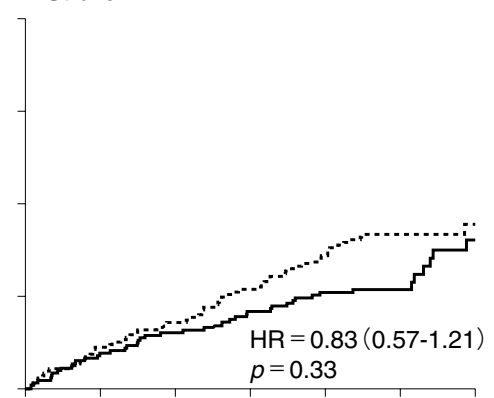

$\begin{array}{lllllll}3966 & 3764 & 3653 & 3534 & 3445 & 2489 & 839\end{array}$ $\begin{array}{lllllll}3866 & 3641 & 3493 & 3390 & 3315 & 2452 & 868\end{array}$

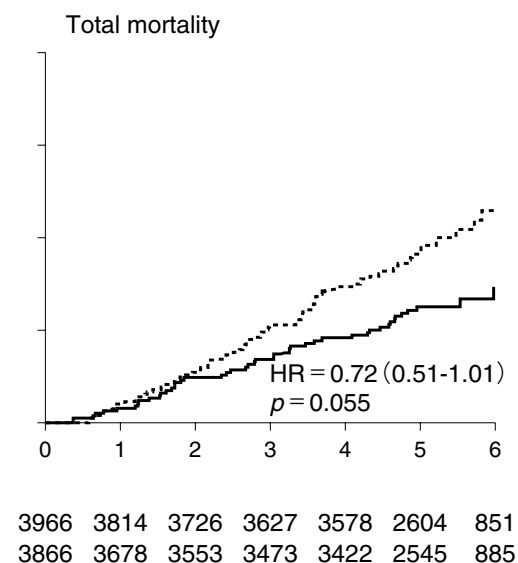

Fig. 2. Kaplan-Meier curves for primary and secondary endpoints in the MEGA study. Adapted from reference 18 . larization procedure was reduced by $33 \%(p=0.010)$ $(3.3 / 1000$ patient years in the diet plus pravastatin group compared to 5.0/1000 patient years in the diet group), and the number needed to treat was 119 (Fig. 2). The onset of CHD and/or cerebral infarction fell with pravastatin therapy by $30 \%(p=0.005)$ and number needed to treat was 91. All cardiovascular events fell by $26 \%$ ( $p=0.01$; number needed to treat, $91)$ and total mortality by $28 \%(p=0.055)$ with paravastatin therapy. No clinically significant difference was found between groups with severe adverse events or cancer. These results demonstrated that 10 to 20 $\mathrm{mg}$ pravastatin reduced the CHD risk in low-risk population the same as the primary prevention trials with 20 to $40 \mathrm{mg}$ of pravastatin in the West. The benefit of pravastatin for the reduction of CHD incidence was more likely to be seen in men aged older than 60 years, and baseline LDL-C levels higher than $155 \mathrm{mg} /$ dL compared with those counterparts. The MEGA study had the largest number of postmenopausal women in the primary prevention study with statins. Sig- nificant risk reduction of stroke and CHD plus cerebral infarction was found in older women aged $\geqq 55$ years. In addition, the reduction of total mortality was found regardless of age, although pravastatin therapy could not achieve a significant risk reduction of the incidence of CHD in women. Further sub-analysis may prove the mechanism of reduced non-CHD death in women ${ }^{53)}$.

\section{The Japan EPA Lipid Intervention Study (JELIS)}

The JELIS is the first large scale, prospective RCT in Asia including both primary $(n=14981)$ and secondary prevention strata. $(n=3664)$ to test the hypothesis that treatment with highly purified $(>98 \%)$ EPA in addition to statin would be more effective than treatment with statin alone in reducing major coronary events in hypercholesetrolemic patients. In this study, 7832 hypercholesterolemic patients, men aged 40 to 75 years and postmenopausal women aged under 75 years, TC levels $\geqq 250 \mathrm{mg} / \mathrm{dL}$ were randomly allocated to statin therapy (pravastatin $10 \mathrm{mg}$ daily 


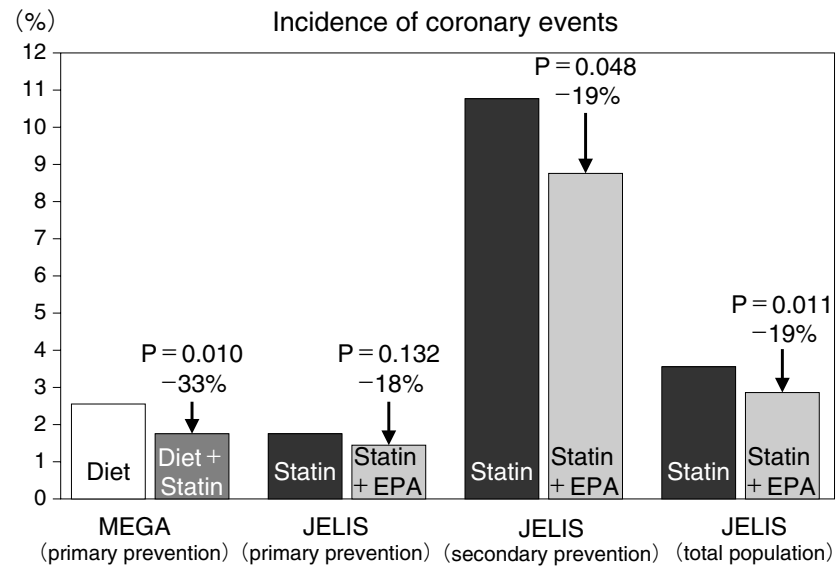

Fig. 3. Comparison of the incidence of coronary events among patients with diet therapy and with pravastatin plus diet in MEGA, and those with statin therapy and statin plus EPA therapy in JELIS. Based on references 18 and 19. The coronary events were defined as fatal or nonfatal MI, angina pectoris, cardiac or sudden death, and coronary revascularization.

or simvastatin $5 \mathrm{mg}$ daily) or statin plus EPA (1800 mg daily) ${ }^{19}$. Measurement of the plasma fatty acid fraction revealed the EPA/arachidonic acid ratio from 0.63 at the baseline to 1.23 at 5 years in the EPA plus statin group and from 0.60 to 0.59 in the statin group. The HDL-C levels showed 5\% and 3\% increases by treatment with EPA plus statin and statin alone, respectively, at 5 years. On the other hand, significant reductions in LDL-C levels were $26 \%$ in both groups $(133 \mathrm{mg} / \mathrm{dL})$. At a mean follow-up of $4.6 \pm 1.1$ years, the composite incidence of sudden cardiac death, fatal and non-fatal myocardial infarction, unstable angina pectoris and coronary revascularization therapy was significantly $19 \%$ lower in the EPA plus statin group than the statin alone group $(2.8 \%$ vs $3.5 \%$, $p=0.0113)$. Fig. 3 compares the incidence of CHD in the first occurrence and recurrence of CHD in MEGA study and JELIS. The incidence of the first occurrence of CHD was similar between pravastatin-treated patients in MEGA and statin-treated patients in JELIS, regardless of the different LDL-C reduction and different baseline LDL-C levels. Significant risk reduction by supplemented EPA was observed in the secondary prevention stratum in JELIS $(8.7 \%$ vs $10.7 \%$, $\mathrm{HR}=0.810,95 \% \mathrm{CI} 0.657-0.998 ; p=0.0476)$. This study demonstrated that the addition of EPA to statin therapy provided further benefits in preventing major coronary events including coronary revascularization, unstable angina and non-fatal coronary events, regardless of no further reduction of LDL-C levels. Many epidemiological studies and secondary prevention studies with fish intake and/or supplementary omega-3 polyunsaturated fatty acids have shown the beneficial effects of fish intake on CHD events and sudden death in the world; on the other hand, it remains controversial whether omega-3 fatty acid has beneficial effects for CHD prevention in the Japanese population living in Japan, where $95 \%$ of adults eat fish at least once a week and the average fish intake is around 100 g/day ${ }^{54,55)}$. A 19-year follow-up prospective study of the NIPPON DATA $80^{54)}$ has failed to show beneficial effects of fish consumption for reducing all-cause and/or CVD death whereas the Japan Public Health Center-Based study with 41578 men and women aged 40 to 59 years has shown that a high fish intake (8 times a week or $180 \mathrm{~g} /$ day) is associated with the reduction of non-fatal coronary events compared with a modest fish intake of once a week or less than 23 $\mathrm{g} /$ day $^{55)}$. The JELIS has indicated that elevated levels of plasma EPA by the addition of EPA to statin therapy has the beneficial effects of CHD prevention through non-LDL-C lowering.

\section{Treatment for Hyperlipidemia from the Viewpoint of Japanese Evidence}

Similar to Western countries, Japanese epidemiological studies have clearly shown that hypercholesterolemia, hypertriglyceridemia, and low HDL-C are strongly associated with increased CHD risk independently of each other. Furthermore, a clustering of risk factors further enhanced the increased CHD risk. Similar to ATP-III, the Japanese guidelines 2002 have shown that the lipid management goal is modified by the presence of other risk factors (Table 4). The recent ATP-III guidelines indicate that LDL-C levels of 100 $\mathrm{mg} / \mathrm{dL}$ are the minimal goal for high-risk patients and recommend an optional therapeutic target of LDL-C less than $70 \mathrm{mg} / \mathrm{dL}$ in very high-risk patients such as those with acute coronary syndrome and diabetic patients with CHD. However, it remains controversial whether a threshold of LDL-C levels for CHD prevention really exists ${ }^{2}$. As the lipid-lowering intensity of each statin has been shown to be dose-dependent ${ }^{56}$, it is conceivable that aggressive lipid lowering by highdose atorvastatin has shown more intensive LDL-C lowering. However, it remains to be determined whether beneficial effects of aggressive lipid-lowering therapy can be seen in primary prevention, in CHD patients with relatively low LDL-C levels $(<125 \mathrm{mg} / \mathrm{dL})$, and can result in the prevention of CHD death ${ }^{57-59)}$. A recent meta-analysis of $10 \mathrm{RCTs}$ with statins using the method of L'Abbé plot ${ }^{60)}$ demonstrated that the relative risk reduction of fatal CHD and non-fatal myo- 
Table 4. Lipid management goals by patient category. Adapted from reference 1

\begin{tabular}{|c|c|c|c|c|c|c|}
\hline \multirow{2}{*}{ Category } & \multirow{2}{*}{ CHD history* } & \multirow{2}{*}{$\begin{array}{l}\text { Major CHD risk factors } \\
\text { other than LDL-C** }\end{array}$} & \multicolumn{4}{|c|}{ Lipid management goal (mg/dL) } \\
\hline & & & T-C & LDL-C & HDL-C & triglyceride \\
\hline A & \multirow{5}{*}{ Absent } & 0 & $<240$ & $<160$ & \multirow{6}{*}{$\geqq 40$} & \multirow{6}{*}{$<150$} \\
\hline B1 & & 1 & & & & \\
\hline B2 & & 2 & $<\angle 20$ & $<140$ & & \\
\hline B3 & & 3 & \multirow{2}{*}{$<200$} & \multirow{2}{*}{$<120$} & & \\
\hline B4 & & 4 or more & & & & \\
\hline $\mathrm{C}$ & Present & & $<180$ & $<100$ & & \\
\hline
\end{tabular}

*: Coronary heart disease (CHD) is defined as myocardial infarction and symptomatic angina pectoris. **: Major CHD risk factors other than LDL-C: age ( $\geqq 45$ for men, $\geqq 55$ for women); hypertension; diabetes mellitus or glucose intolerance; cigarette smoking; family history of CHD; low HDL-C. Diabetes mellitus is regarded as B3 risk equivalent. Cerebral infarction and arteriosclerosis obliterans are regarded as B4 risk equivalent.

cardial infarction is comparable $(-25 \%)$ among pravastatin, simvastatin, and atorvastatin irrespective of their different doses and different risk populations. Another recent meta-analysis of data from 14 RCTs of statins ${ }^{61)}$ has shown an approximately linear relationship between the absolute reductions in LDL-C and the proportional reductions in $\mathrm{CHD}$ and other events, that is, the risk reduction by lowering LDL-C from 155 to $116 \mathrm{mg} / \mathrm{dL}$ is similar to that from 116 to $77 \mathrm{mg} / \mathrm{dL}$, which suggests that achieving a substantial absolute reduction in LDL-C is more important than achieving particular target levels of LDL-C (Fig. 4). In the MEGA study, only $23 \mathrm{mg} / \mathrm{dL}$ reduction of LDL-C resulted in $33 \%$ risk reduction of CHD in a low-risk population, the same as about $40 \mathrm{mg} / \mathrm{dL}$ reduction of LDL-C did in Western RCTs. Similarly, PATE showed that a small reduction of LDL-C was enough to reduce the $\mathrm{CHD}$ risk in the Japanese older population. A necessary reduction in LDL-C to achieve beneficial risk reductions may differ between Western and Japanese populations with different lifestyles, body size, and genetics.

A meta-analysis of 97 RCTs to investigate the efficacy of different lipid-lowering interventions has shown that statins and omega-3 fatty acids offer favorable benefits by reducing the risk of cardiac and overall mortality (Fig. 5) ${ }^{62)}$. The JELIS first indicated that the addition of omega-3 fatty acids to statins lead to further prevention of the incidence of major coronary events, especially unstable angina, mainly through LDLC-independent mechanisms. This may be attributed to the inhibition of platelet aggregation, slight increase in HDL-C, modest decrease in triglyceride, and/or anti-inflammatory action ${ }^{63,64)}$. Thus, "the lower is better" may not be proved in Japanese hypercholesterolemic patients. Further sub-analysis may prove which
Proportional reduction in event rate

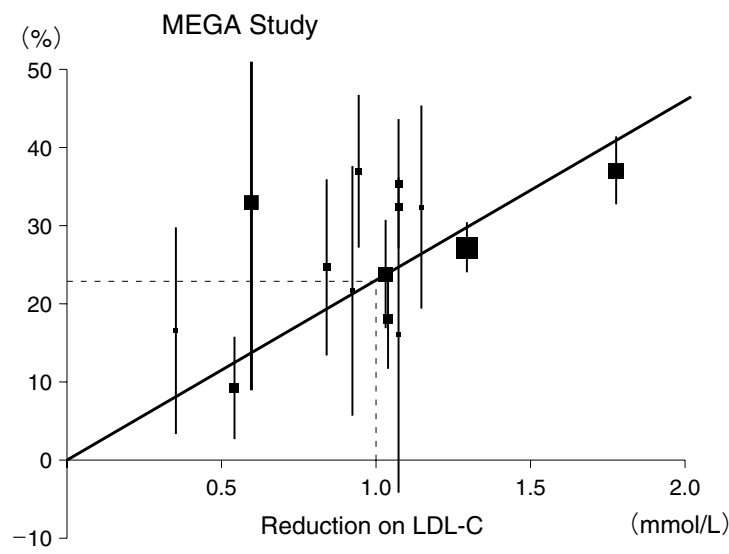

Fig.4. Relation between proportional reduction in the incidence of major coronary events and mean absolute LDL-C reduction at 1 year. Square represents a single trial plotted against mean absolute LDL-C reduction with vertical lines above and below corresponding to one SE of unweighted event rate reduction. The overall incidence was reduced by $25 \%$ per $1 \mathrm{mmol} / \mathrm{L}$ $(=38.46 \mathrm{mg} / \mathrm{dL})$ reduction in LDL-C. The relative reduction of major coronary events in the MEGA study was placed above the line of the relationship between absolute LDL-C reduction and reduction of CHD events in 14 randomized clinical trials conducted in the West. Adapted from reference 61.

patients have more benefit of lipid-lowering drugs. Pharmacogenetic studies have shown that the lipid response and adverse effects of drugs may be related in part to genetic variations in individuals ${ }^{65)}$; evidence for Caucasians is not always the same for Japanese, and evidence for pravastatin is not always the same for to other statins. Further studies are required to deter- 


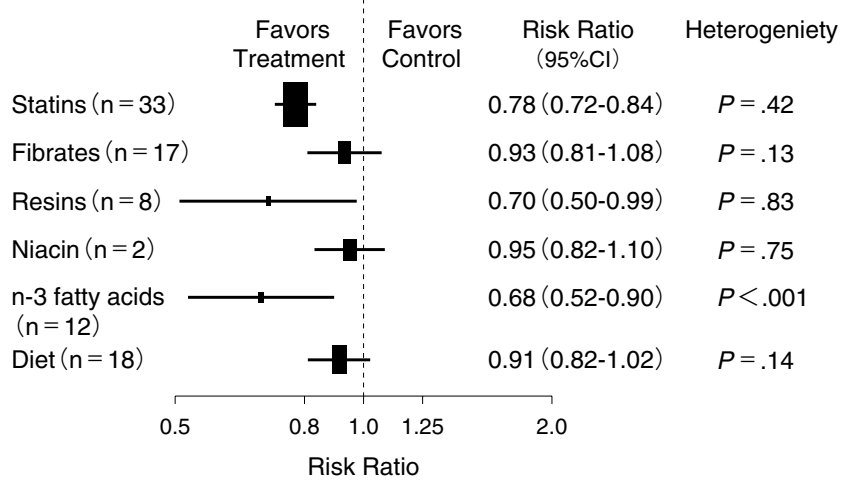

Fig. 5. Summary estimates for cardiac mortality for different types of lipid-lowering interventions. The Cochrane Q test for heterogeneity.

$\mathrm{N}=$ number of trials available for analysis. $\mathrm{n}-3 \mathrm{FA}=\mathrm{n}-3$ fatty acid. Adapted from reference 62.

mine the effects of different statins in high-risk Japanese populations.

Adverse effects such as the elevation of liver enzyme and discontinuation of statins were more frequent in high-dose atorvastatin compared with oth$e^{25}{ }^{58,59)}$. On the other hand, it remains controversial whether low LDL-C concentrations relate to an increased risk of cerebral hemorrhage and/or cancer mortality $\left.{ }^{25}, 47,66-69\right)$. Patients with low TC often had low LDL-C and/or low HDL-C. This may be attributed to not hyper-responders to statins but low lipid levels caused by underlying malignancy. Recent reports of meta-analysis of RCTs have shown that stains have a neutral effect on cancer and cancer death ${ }^{61,67)}$. In the MEGA study and KLIS, incidences of adverse effects such as elevated serum liver enzymes and any type of cancer were similar between the pravastatin group and diet or conventional therapy group. Thus, the standard dose of pravastatin and simvastatin are safe for Japanese patients.

The intake of fat and incidence of obesity have been increasing with lifestyle westernization, and it is of great concern that both the mortality and morbidity of CHD may shift to increasing trends soon or later. It must be emphasized that all guidelines place a major emphasis on lifestyle modification such as diet therapy, weight loss for those overweight, cessation of smoking, and increased physical activity as essential therapy for hyperlipidemia ${ }^{1-3)}$. Lipid-lowering drug therapy has additive and/or synergistic beneficial effects in some patients, and the absolute benefit depends on the absolute risk. As adherence with drug treatment is very important, we should choose drugs proved as safe by evidence.

\section{References}

1) Saito Y: The Japan Atherosclerosis Society Guidelines for Diagnosis and Treatment of Atherosclerotic Cardiovascular Disease 2002 (Editorial). J Atheroscler Thromb, 2004; 11:101-103

2) Grundy SM, Cleeman JI, Merz NB, Brewer Jr B, Clark LT, Hunninghake DB, Pasternak RC, Smith Jr SC, Stone NJ, for the coordinating committee of the National Education Program. Implications of recent clinical trials for the National Cholesterol Education Program Adult Treatment Panel III Guidelines. Circulation, 2004; 110:227239

3) De Backer G, Ambrosioni E, Borch-Johnsen K, Brotons C, Cifkova R, Dallongeville J, Ebrahim S, Faergeman O, Graham I, Mancia G, MangerCats V, Orth-Gomér K, Perk J, Pyörälä K, Rodicio JL, Sans S, Sansoy V, Sechtem U, Silber S, Thomsen T, and Wood D: European guidelines on cardiovascular disease prevention in clinical practive: Third Joint Task Force of European and other societies on cardiovascular disease prevention in clinical practice (constituted by representatives of eight societies and by invited experts). Eur Heart J, 2003; 24:1601-1610

4) Ginsberg HN: Identification and treatment of hypertriglyceridemia as a risk factor for coronary heart disease. Curr Cardiol Reports, 1999; 1:233-237

5) Scandinavian Simvastatin Survival Study Group. Randomised trial of cholesterol lowering in 4444 patients with coronary heart disease: the Scandinavian Simvastatin Survival Study (4). Lancet, 1994; 344:1383-1389

6) Shepherd J, Cobbe SM, Ford I, Isles CG, Lorimer AR, Macfarlane PW, McKillop JH, Packard CJ, for the West of Scotland Coronary Prevention Study Group. Prevention of coronary heart disease with pravastatin in men with hypercholesterolemia. N Engl J Med, 1995; 333:13011307

7) Sacks FM, Pfeffer MA, Moye LA, Rouleau JL, Rutherford JD, Cole TG, Brown L, Warnica JW, Arnold JMO, Wun CC, Davis BR, Braunwald E, for the Cholesterol and Recurrent Trial Investigators. The effect of pravastatin on coronary events after myocardial infarction in patients with average cholesterol levels. N Eng J Med, 1996; 335:10011009

8) Downs JR, Clearfield M, Weis S, Whitney E, Shapiro D, Beere PA, Langendorfer A, Stein EA, Kruyer W, Gotto Jr AM, for the AFCAPS/TexCAPS Research Group. Primary prevention of acute coronary events with lovastatin in men and women with average cholesterol levels: results of AFCAPS/TeCAPS. JAMA, 1998; 279:1615-1662

9) The Long-Term Intervention with Pravastatin Ischemic Disease (LIPID) Study Group. Prevention of cardiovascular events and death with pravastatin in patients with coronary heart disease and a broad range of initial cholesterol levels. N Engl J Med, 1998; 339:1349-1357

10) Shepherd J, Blauw GJ, Murphy MB, Bollen ELE, Buckley BM, Cobbe SM, Ford I, Gaw A, Hyland M, Jukema JW, Kamper AM, Macfarlane PW, Meinders AE, Norrie J, Packard CJ, Perry I, Stott DJ, Sweeney BJ, Twomey C, Westendorp RG, on behalf of the PROSPER study group. Pravastatin in elderly individuals at rsik of vascular disease 
(PROSPER): a randomized controlled trial. Lancet, 2002; 360:1623-1630

11) Sever PS, Dahlöf B, Roulter NR, Wedel H, Beevers G, Caulfield M, Collins R, Kjeldsen SE, Kristinsson A, Mclnnes GT, Mehlsen J, Nieminen M, O’Brien E, Östergren J, for the ASCOT investigators. Prevention of coronary and stroke events with atorvastatin in hypertensive patients who have average or lower-than-average cholesterol concnentrtaions, in the Anglo-Scandinavian Cardiac Outcomes Trial-Lipid Lowering Arm (ASCOT-LLA): a multicenter randomized controlled trial. Lancet, 2003; 361:1149-1158

12) Heart Protection Study Collaborative Group. MRC/BHF Heart Protection study of cholesterol lowering with simvastatin in 20536 high-risk individuals: a randomized placebo-controlled trial. Lancet, 2002; 360:7-22

13) Colhoun HM, Betteridge DJ, Durrington PN, Hitman G, Neil HAW, Livingstone SJ, Thomason MJ, Mackness KI, Charlton-Menys V, Fuller JH, on behalf of the CARDS investigators. Primary prevention of cardiovascular disease with atorvastatin in type 2 diabetes in the Collaborative Atorvastatin Diabetes Study (CARDS): multicentre randomized placebo-controlled trial. Lancet, 2004; 364:685696

14) Athyros VG, Papageorgiou AA, Mercouris BR, Athyrou VV, Symeonidis AN, Basayannis EO, Dermitriadis DS, and Kontopoulos AG: Treatment with atorvastatin to the National Cholesterol Education program goal versus 'usual' care in secondary coronary heart disease preventionthe GREek Atorvastatin and Coronary heart disease Evaluation (GREACE) study. Curr Med Res Opin, 2002; 18:220-228

15) Kubo M, Kiyohara Y, Kato I, Tanizaki Y, Arima H, Tanaka K, Nakamura H, Okubo K, and Iida M: Trends in the incidence, mortality, and survival rate of cardiovascular disease in a Japanese community: the Hisayama study. Stroke, 2003; 34:2349-2354

16) Sytkowski PA, D’Agostino RB, Belanger A, and Kannel WB: Sex and time trends in cardiovascular disease incidence and mortality: the Framingham Heart Study, 19501989. Am J Epidemiol, 1996; 143:338-350

17) Yoshida M, Kita Y, Nakamura Y, Nozaki A, Okayama A, Sugihara H, Kasamatsu T, Hirose K, Kinoshita M, and Ueshima H: Incidence of acute myocardial infarction in Takashima, Shiga, Japan. Circ J, 2005; 69:404-408

18) Nakamura $H$, Arakawa K, Itakura $H$, Kitabatake A, Goto Y, Toyota T, Nakaya N, Nishimoto S, Muranaka M, Yamamoto A, Mizuno K, Ohashi Y, for the MEGA Study Group. Primary prevention of cardiovascular disease with pravastatin in Japan (MEGA Study): a prospective randomized controlled trial. Lancet, 2006; 368:1155-1163

19) Yokoyama M: Effects of eicosapentaenoic acid (EPA) on major cardiovascular events in hyperchoelsterolemic patients: the Japan EPA Lipid Intervention Study (JELIS). Circulation, 2005; 112:3362 [abstract]

20) Kodama K, Sasaki H, and Shimizu Y: Trend of coronary heart disease and its relationship to risk factors in a Japanese Population: A 26-year follow-up, Hiroshima/Nagasaki Study. Jpn Circ J, 1990; 54:414-421

21) Benfante R: Studies of cardiovascular disease and cause- specific mortality trends in Japanese-American men living in Hawaii and risk factor comparison with other Japanese populations in the Pacific region: A review. Hum Biol, 1992; 64:791-805

22) Kromhout D: On the waves of the Seven Countries Study. A public health perspective on cholesterol. Eur Heart J, 1999; 20:796-802

23) Arai H, Yamamoto A, Matsuzawa Y, Saito Y, Yamada N, Oikawa S, Mabuchi H, Teramoto T, Sasaki J, Nakaya N, Itakura H, Ishikawa Y, Ouchi Y, Horibe H, Kita T, on behalf of the Research Group on Serum Lipid Level Survey 2000 in Japan. J Atheroscler Thromb, 2005; 12:98-106

24) Okamura T, Kadawaki T, Hayakawa T, Kita Y, Okayama A, Ueshima H, for the NIPPON DATA 80 Research Group. What cause of mortality can we predict by cholesterol screening in the Japanese general population? J Intern Med, 2003; 253:169-180

25) Okamura T, Tanaka H, Miyamatsu N, Hayakawa T, Kadowaki T, Kita Y, Nakamura Y, Okayama A, Ueshima H, for the NIPPON DATA 80 research group. The relationship between serum total cholesterol and all-cause or cause-specific mortality in a 17.3 year study of a Japanese cohort. Atherosclerosis 2006, Mar 8 [Epub ahead of print]

26) Wakugami K, Iseki K, Kimura Y, Okumura K, Ikemiya $Y$, Muratani H, and Fukiyama K: Relationship between serum cholesterol and the risk of acute myocardial infarction in a screened cohort in Okinawa, Japan. Jpn Circ J, 1998; 62:7-14

27) Tanizaki Y, Kiyohara Y, Kato I, Iwamoto H, Nakayama K, Shinohara N, Arima H, Tanaka K, Ibayashi S, and Fujishima M: Incidence and risk factors for subtypes of cerebral infarction in a general population. The Hisyama Study. Stroke, 2000; 31:2616-2622

28) NIPPON DATA 80 Research Group. Risk assessment chart for death from cardiovascular disease based on a 19-year follow-up study of a Japanese Representative Population-NIPPON DATA 80- . Circ J, 2006; 70:12491255

29) Tanaka H, Date C, Chen H, Nakayama T, Yokoyama T, Yoshiike N, Iwaoka H, Iwaya M, Zaman MM, Yamaguchi M, Matsumura Y, Sugiyama M, Kushiro W, Ichimura T, Noji A, Chowdhury AH, Kim IS, Kwan TB, and Cho BM: A brief review of epidemiological studies on ischemic heart disease in Japan. J Epidemiol, 1996; 6:S49-S59

30) Konishi M, Iso H, Iida M, Naito Y, Sato S, Komachi Y, Shimamoto T, Doi M, and Ito M: Trends for coronary heart disease and its risk factors in Japan: Epidemiologic and pathologic studies. Jpn Circ J, 1990; 54:428-437

31) Okayama A, Ueshima H, Marmot M, Elliott P, Choudhury SR, and Kita Y: Generational and regional differences in trends of mortality from ischemic heart disease in Japan from 1969 to 1992. Am J Epidemiol, 2001; 153:11911198

32) Khoo KL, Tan H, Liew YM, Deslypere JP, and Janus E: Lipids and coronary heart disease in Asia. Atherosclerosis, 2003; 169:1-10

33) Iso $H$, Naito $Y$, Sato $S$, Kitamura A, Okamura T, Sankai T, Shimamoto T, Iida M, and Komachi Y: Serun triglycerides and risk of coronary heart disease among Japanese men and women. Am J Epidemiol, 2001; 153:490-499 
34) Asia Pacific Cohort Collaboration. Serum triglyceride as a risk factor for cardiovascular diseases in the Asia-Pacific Region. Circulation, 2004; 110:2678-2686

35) Asia Pacific Cohort Collaboration. A comparison of lipid variables as predictors of cardiovascular disease in the Asia Pacific region. Ann Epidemiol, 2005; 15:405-413

36) Grundy SM, Cleeman JI, Daniels SR, Donate KA, Eckel RH, Franklin BA, Gordon DJ, Krauss RM, Savage PJ, Smith Jr SC, Spertus JA, and Costa F: Diagnosis and Management of the Metabolic syndrome An American Association/National Heart, Lung, and Blood Institute Scientific Statement. Circulation, 2005; 112:2735-2752

37) Zimmet P, Magliano D, Matsuzawa Y, Albert G, and Shaw J: The Metabolic syndrome: A global public healthy problem and a new definition. J Atheroscler Thromb, 2005; 12:295-300

38) Kukita H, Hamada M, Hiwada K, and Kokubu T: Clinical significance of measurement of serum apolipoprotein A-I, A-II and B in hypertriglyceridemic male patients with and without coronary artery disease. Atherosclerosis, 1985; 55:143-149

39) Washio M, Sasazuki S, Kodama H, Yoshimasu K, Liu YK, Tanaka K, Tokunaga S, Kono S, Arai H, Koyanagai S, Hiyamuta K, Doi Y, Kawano T, Nakagaki O, Takada K, Nii T, Shirai K, Ideishi M, Arakawa K, Mohri M, and Takeshita A: Role of hypertension, dyslipidemia and diabetes mellitus in the development of coronary atherosclerosis in Japan. Jpn Circ J, 2001; 65:731-737

40) Koba S, Hirano T, Kondo T, Shibata M, Suzuki H, Murakami M, Geshi E, and Katagiri T: Significance of small dense low-density lipoproteins and other risk factors in patients with various types of coronary heart diseases. Am Heart J, 2002; 144:1026-1035

41) Koba S, Hirano T, Ito Y, Tsunoda F, Yokota Y, Ban Y, Iso Y, Suzuki H, and Katagiri T: Significance of small dense lowdensity lipoprotein-cholesterol concentrations in relation to the severity of coronary heart diseases. Atherosclerosis, 2006; 189:206-214

42) Kitamua $A$, Iso $H$, Naito $Y$, Iida M, Konishi M, Folsom AR, Sato S, Kiyama M, Nakamura M, Sankai T, Shimamoto T, and Komachi Y: High-density lipoprotein cholesterol and premature coronary heart disease in urban Japanese men. Circulation, 1994; 89:2533-2539

43) St-Pierre AC, Cantin B, Dagenais GR, Mauriege P, Bernard PM, Despres JP, and Lamarche B: Low-density lipoprotein subfractions and the long-term risk of ischemic heart disease in men: 13-year follow-up data from the Quebec Cardiovascular Study. Arterioscler Thromb Vasc Biol, 2005; 25:553-559

44) Kathiresan S, Gona P, Larson MG, Vita JA, Mitchell GF, Tofler GH, Levy D, Newton-Cheh C, Wang TJ, Benjamin EJ, and Vasan RS: Increased small low-density lipoprotein particle number. A prominent feature of the Metabolic syndrome in the Framingham Heart Study Circulation, 2006; 113:20-29

45) Austin MA, Rodriguez BL, McKnight B, McNeely MJ, Edwards KL, Curb JD, and Sharp DS: Low-density lipoprotein particle size, triglyceride, and high-density liporpotein cholesterol as risk factors for coronary heart disease in older Japanese-American men. Am J Cardiol, 2000;
86:412-416

46) Matsuzawa $Y$, Itakura H, Kita T, Mabuchi H, Mastuzaki M, Nakaya N, Oikawa S, Saito Y, Sasaki J, Shimamoto K, the J-LIT Study Group. Design and baseline characteristics of a cohort study in Japanese patients with hypercholesterolemia: The Japan Lipid Intervention Trial (J-LIT). Curr Ther Res, 2000; 61:219-243

47) Matsuzaki M, Kita T, Mabuchi H, Matsuzawa Y, Nakaya N, Oikawa S, Saito Y, Sasaki J, Shimamoto K, Itakura H, and the J-LIT Study Group. Large-scale cohort study of the relationship between serum cholesterol concentration and coronary events with low-dose simvastatin therapy in Japanese patients with hypercholesterolemia - primary prevention cohort study of the Japan Lipid Intervention Trial (J-LIT) - . Circ J, 2002; 66:1087-1095

48) Mabuchi H, Kita T, Matsuzaki M, Matsuzawa Y, Nakaya N, Oikawa S, Saito Y, Sasaki J, Shimamoto K, Itakura H, and the J-LIT Study Group. Large-scale cohort study of the relationship between serum cholesterol concentration and coronary events with low-dose simvastatin therapy in Japanese patients with hypercholesterolemia and coronary heart disease - secondary prevention cohort study of the Japan Lipid Intervention Trial (J-LIT) - . Circ J, 2002; 66:1096-1100

49) Nakaya N, Kita T, Mabuchi H, Matsuzaki M, Matsuzawa Y, Oikawa S, Saito Y, Sasaki J, Shimamoto K, Itakura H, and the J-LIT Study Group. Large-scale cohort study on the relationship between lipid concentrations and risk of cerebrovascular disease under low-dose simvastatin in Japanese patients with hypercholesterolemia - sub-analysis of the Japan Lipid Intervention Trial (J-LIT) - . Circ J, 2005; 69:1016-1021

50) The Kyushu Lipid Intervention Study Group. Pravasatin use and risk of coronary events and cerebral infarction in Japanese men with moderate hypercholesterolemia: The Kyushu Lipid Intervention Study. J Atheroscler Thromb, 2000; 7:110-121

51) Iwashita M, Matsushita Y, Sasaki J, Arakawa K, Kono S, for the Kyushu Lipid Intervention Study (KLIS) Group. Relation of serum total cholesterol and other risk factors to risk of coronary events in middle-aged and elderly Japanese men with hypercholesterolemia - The Kyushu Lipid Intervention Study - . Circ J, 2004; 68:405-409

52) Ito $H$, Ouchi $Y$, Ohashi $Y$, Saito $Y$, Ishikawa $T$, Nakamura $\mathrm{H}$, and Orimo $\mathrm{H}$ : A comparison of low versus standard dose pravastatin therapy for the prevention of cardiovascular events in the elderly: The Pravastatin Anti-atherosclerosis Trial in the Elderly (PATE). J Atheroscler Thromb, 2001; 8:33-44

53) Mizuno K, Nakamura H, MEGA Study Group. Marked risk reduction in coronary heart disease, stroke and total mortality in women $\geqq 60$ years old with low-dose pravastatin for primary prevention in the Management of Elevated Cholesterol in the Primary Prevention Group of Adult Japanese (MEGA) Study. J Am Coll Cardiol, 2006; 47:354A [abstract]

54) Nakamura $Y$, Ueshima H, Okamura T, Kadowaki T, Hayakawa T, Kita Y, Tamaki S, Okayama A, for the NIPPON DATA 80 Research Group. Association between fish consumption and all-cause and cause-specific mortality in Ja- 
pam: NIPPON DATA 80, 1980-1999. Am J Med, 2005; 118:239-245

55) Iso H, Kobayashi M, Ishihara J, Sasaki S, Okada K, Kita Y, Kokubo Y, Tsugane S, for the JPHC Study Group. Intake of fish and n3 fatty acids and risk of coronary heart disease among Japanese: The Japan Public Healthy CenterBased (JPHC) Study Cohort I. Circulation, 2006; 113:195202

56) Law MR, Wald NJ, and Rudnicka AR: Quantifying effect of statins on low density lipoprotein cholesterol, ischaemic heart disease, and stroke: systematic review and meta-analysis. BMJ, 2003; 326:1423-1427

57) Cannon CP, Branwald E, McCabe CH, Rader DJ, Rouleau JL, Belder R, Joyal SV, Hill KA, Pfeffer MC, Skene AM, for the Pravastatin or Atorvastatin Evaluation and Infection Therapy-Thrombolysis in Myocardial Infarction 22 Investigators. Comparison of intensive and moderate lipid lowering with statins after acute coronary syndromes. N Engl J Med, 2004; 350:1495-1504

58) LaRosa JC, Grundy SM, Waters DD, Shear C, Barter P, Fruchart JC, Gotto AM, Greten H, Kastelein JJP, Shepherd J, Wenger NK, for the Treating to New Targets (TNT) Investigators. Intensive lipid lowering with atorvastatin in patients with stable coronary disease. $\mathrm{N}$ Engl J Med, 2005; 352:1425-1435

59) Pedersen TR, Faergeman O, Kastelein JJ, Olsson AG, Tikkanen MJ, Holme I, Larsen ML, Bendiksen FS, Lindahl C, Szarek M, Tsai J, for the Incremental Decrease in End Points Through Aggressive Lipid Lowering (IDEAL) Study Group. JAMA, 2005; 294:2437-2445

60) Zhou Z, Rahme E, and Pilote L: Are statins created equal? Evidence from randomized trials of pravastatin, simvastatin, and atorvastatin for cardiovascular disease prevention. Am Heart J, 2006; 151:273-281
61) Cholesterol Treatment Trialists' (CTT) Collaborators. Efficacy and safety of cholesterol-lowering treatment: prospective meta-analysis of data from from 90056participants in 14 randomised trials of sataints. Lancet, 2005; 366:1267-1278

62) Studer M, Briel M, Leimenstoll B, Glass TR, and Bucher HC: Effect of different antilipidemic agents and diets on mortality: A systematic review. Arch Intern Med, 2005; 165:725-730

63) Stone NJ: Fish consumption, fish oil, lipids, and coronary heart disease. Circulation, 1996; 94:2337-2340

64) Prescott SM and Stenson WF: Fish oil fix. Nature Med, 2005; 11:596-598

65) Kajinami K, Okabayashi M, Sato R, Polisecki E, and Schaefer EJ: Statin pharmacogenomics: what have we learned, and what remains unanswered? Curr Opin Lipid, 2005; 16:606-613

66) Jacobs D, Blackburn H, Higgins M, Reed D, Iso H, McMillian G, Neaton J, Nelson J, Potter J, Rifkind B, Rossouw J, Shekelle R, Yusuf S, for Participants in the Conference on Low Cholesterol: Mortality Associations. Report of the conference on low blood cholesterol: Mortality associations. Circulation, 1992; 86:1046-1060

67) Dale KM, Coleman CJ, Henyan NN, Kluger J, and White CM: Stains and cancer risk: A meta-analysis. JAMA, 2006; 295:74-80

68) Okumura K, Iseki K, Wakugami K, Kimura Y, Muratani $\mathrm{H}$, Ikemiya $\mathrm{Y}$, and Fukiyama K: Low serum cholesterol as a risk factor for hemorrhagic stroke in men: A community-based mass screening in Okinawa, Japan. Jpn Circ J, 1999; 63:53-58

69) Eastern Stroke and Coronary Heart Disease Collaborative Research Group. Blood pressure, cholesterol, and stroke in eastern Asia. Lancet, 1998; 352:1801-1807 